\title{
Digital Disinformation and Communalism in Bangladesh
}

\author{
Md. Sayeed Al-Zaman \\ Jahangirnagar University, Savar, Dhaka, Bangladesh
}

\begin{abstract}
Traditional society of Bangladesh has been enduring explicit transformation. Individuals' increasing income, flourishing consumer culture, and security in social life as a cumulative force smooths the scope of modern global amenities to come in and grow up amid this changing society. Of them, new age digital communication is vital one. Digital media is encompassing people's everyday life. Process of acquiring information has also changed remarkably: instead of searching to get one, people now struggle to look for reliable information due to ample information. Cyberspace becomes the cornucopia of fluid information that often baffles the surfers by providing distorted information. Bangladesh has been experiencing digital media-initiated disinformation from the beginning of 2010s. Interest groups are playing with digital disinformation conjoining religious sentiment. As a result, incidents of assault on religious minorities based on digital (dis)information have become frequent. Considering the importance of digital disinformation instigating communalism in Bangladesh, this study explores the nature of contemporary digital communalism and violence on religious minorities. It has been seen that beyond mere religious sentimentalism and sensationalism, historical and political along with several other factors significantly contribute to these atrocities.
\end{abstract}

Keywords: disinformation, religion, communal violence, social media, digital communalism, minority [Md. Sayeed Al-Zaman. Digital Disinformation and Communalism in Bangladesh. China Media Research, 15(2):68-76]

\section{Introduction}

In October 2017, Israeli police mistakenly arrested a Palestinian construction worker after the Artificial Intelligence (AI) of Facebook mistranslated a post. The man posted his photo leaning against a bulldozer with a caption "yusbihuhum" in Arabic (Hern, 2017), which should be translated as "good morning" in English. However, Facebook's automatic translation system Bing converted it as "hurt them" in English and "attack them" in Hebrew. The police officers were suspicious as bulldozer has been used in hit-and-run attack upon them beforehand. Hence, they suspected the man is threatening them. Consequently, they arrested him immediately, and afterwards, realized their mistake (Berger, 2017). Such intentional and unintentional as well as unexpected incidents, and promulgation of falsified information are increasing in the $21^{\text {st }}$ Century due to the mushrooming usage of digital media and intense communication.

Every interaction is a process of exchanging information. Digital communication produces an unimaginable quantity of information in guise of digital data. Although quality of these information is questionable since everyone can be a producer of information in online. Cyberspace, a vast "ocean of information", works like a magnificent repository of information: authentic, distorted, and even fabricated. Abundant but unfiltered information does not always bring merry but catastrophe too. Corrupted information derived from digital media may deceive individuals which could lead toward social unrest. Impact of digital information is highly influential and navigational in such society where at least three characteristics are present: (a) total number of digital media user is large enough, and the growth is continuing; (b) beyond mainstream media, digital media works as a primary source of information for a significant portion of population; and (c) the users take the information for granted without cross checking. Interestingly, Bangladesh as a developing and economically thriving country is having all these features.

Bangladesh is fostering a fast-growing community of "netizens" (Hauben, 1995) that already has included 83.141 million digital media users (BTRC, 2018). These online denizens work as potential informants who use online media either to receive and diffuse or produce and disseminate information. From the previous few years, Bangladesh has been experiencing incidents of digital disinformation those are enabling serious communal disharmony, distrust, even violence along with religious line. Co-cultural, more precisely, religious minorities are enduring suppression and marginalization not only in physical society but also in cyberspace. Hindu $(8.5 \%)$ and Buddhist $(0.6 \%)$ as the largest religious minority groups in Bangladesh are also the most vulnerable to digital communalism and contempt. Therefore, this study explores four specific queries: how digital media is (a) impeding the peaceful coexistence of religious communities; (b) playing role in inciting aggressive behavior of Muslims, the dominant religious group, against other religious minorities; (c) increasing the communal tension between religious factions; and (d) successfully staging communal violence along religious fault lines. To comprehend the whole ambience, contemporary digital communalism and communal violence on Bangladesh Hindu and Buddhist 
communities, more precisely, two most influential selected cases have been meticulously analyzed along with other remarkable socio-political propensities.

\section{Extrapolating "Digital Disinformation"}

Information is the matured stage of data. Data is a symbol set, raw facts, quantified and/or qualified. Information is the data that is processed and meaningful, and able to create knowledge (Zins, 2007). The DIKW hierarchy (Data $>$ Information $>$ Knowledge $>$ Wisdom) defines how raw data eventually produces information, knowledge, and lastly, wisdom (Rowley, 2007).

Misinformation and disinformation, though pronounced simultaneously, are quite different from semantic aspect. Misinformation is the circulation of false information without intension. In other words, lack of information and knowledge gap cause misinformation. Disinformation is also the dissemination of inaccurate information that is deliberately constructed and disguised to gain intended result.

"Disinformation is simply misinformation purposefully conveyed to mislead the receiver into believing that it is information." (Floridi, 2011:260)

The prefix "dis-" generally means "not" (disagree, disable) and/or the opposite (disestablish, disaffection) both having a negative connotation (G. \& C. Merriam Co., 1961). The term "disinformation" was mainly originated from Russian dezinformatsiya, and borrowed as well as polished by the department of black propaganda of KGB in 1950s (Bittman, 1985). Joseph Stalin coined the term to sound it French to demand falsely its Western origin (Pacepa \& Rychlak, 2013).

In our lives, we alone cannot acquire all the information and knowledge we need so that we must rely on others (Hume, 2007). Thus, defected information succeeds. Besides, debate exists whether information, misinformation, and disinformation are the same thing or not, and whether information should be true, or merely meaningful data. However, disinformation by its nature is different from information and misinformation.

Floridi (1996, 2005, 2011) proposed three different accounts on disinformation: (a) the process of information is defective; (b) the source is aware of its nature; and (c) it is purposefully conveyed to mislead. Therefore, disinformation, as a conscious act, is purposively dissemination of the defected information to misled people. After the so-called " 4 th Industrial Revolution" or AI Revolution, the world in fact has become a hyper-networked place. Six Degrees of Separation postulates "we are all linked by the chains of acquaintance, you are just six introductions away from any other person on the planet" (Smith, 2018). Recently, the world's largest social networking site Facebook, having more than 2 billion users, announced that "each person in the world" is separated from another by "an average of three and a half other people" (Bromwich, 2016). The world is shrinking at a rapid pace in terms of interaction, especially with the gift of new age communication technology, through which production and distribution of information (and disinformation) has become much easier than ever.

\section{Religious Minorities in Bangladesh}

Four major religious communities constitute most of the Bangladesh population: Muslim, Hindu, Buddhist, and Christian. After the Indian partition in 1947, many Bengali Hindus immigrated from Bengal to India, and a flood of Indian Muslims crossed the border and settled in Bengal. Hindu community is the largest and most persecuted religious minority in contemporary Bangladesh where Islam is the dominant religion. Even Islamic sects like Ahmadi and Shi'a Muslims also face oppressions by the majority Sunnis. A comparative illustration of religious communities based on population percentage in every census year (Table 01) shows the decreasing share of religious groups in total population of the country.

\begin{tabular}{|c|c|c|c|c|c|c|c|}
\hline Religious Community & 1951 & 1961 & 1971 & 1981 & 1991 & 2001 & 2011 \\
\hline Muslim & 76.9 & 80.4 & 85.4 & 86.7 & 88.3 & 89.7 & 90.4 \\
\hline Hindu & 22 & 18.5 & 13.3 & 12.1 & 10.5 & 9.2 & 8.5 \\
\hline Buddhist & 0.7 & 0.7 & 0.6 & 0.6 & 0.6 & 0.7 & 0.6 \\
\hline Christian & 0.3 & 0.3 & 0.3 & 0.3 & 0.3 & 0.3 & 0.3 \\
\hline Others & 0.1 & 0.1 & 0.2 & 0.3 & 0.3 & 0.2 & 0.1 \\
\hline
\end{tabular}

Table 01: Composition of Bangladesh religious communities (\%) from 1951 to 2011 Source: Minority Rights Group International (2016). Under Threat: The challenges facing religious minorities in Bangladesh. Sweden: Minority Rights Group. p. 07

The total percentage of Muslim population has been increasing (from $76.9 \%$ in 1951 to $90.4 \%$ in 2011) whereas Hindu community has been getting smaller (from $22 \%$ in 1951 to $8.5 \%$ in 2011) after the partition. Two tendencies are influencing these percentages: (a) Hindu families are shifting in India on a regular basis. 
Daily migration rate of Hindus was 512 in 1971-81 and it reached at 774 in 2001-11. It has been contemplated that, following this rate of exodus, there would be "no" Hindus in Bangladesh after 30 years (Hassan, 2016). The repulsion accelerated under few circumstances, such as oppressions and strategic vandalism, marginalization and psychological torture, legalization and operationalization of the anti-Hindu laws (e.g. Enemy Property Act 1968, later known as Vested Property Act); and (b) fertility rate and annual growth rate of Muslims are higher than any other religious communities.

Between 1965 and 1990 the total number of people on earth rose from 3.3 billion to 5.3 billion, an annual growth rate of 1.85 percent. In Muslim societies growth rates almost always were over 2.0 percent, often exceeded 2.5 percent, and at times were over 3.0 percent. (Huntington, 1996: 117)

Buddhist minority including Marma, Chakma, and few others cliques residing in Chittagong Hill Tracts (CHT) for decades has been being suppressed and ousted by the state-initiative Bengali influx and settlement there. As a result, the ratio of indigenous and Bengali in CHT has been transformed conspicuously from 91:9 in 1951 to 50:50 in 1991 (Mohsin, 2003).

Remaining minority communities are less hammered than the Hindu and Buddhist. A range of religiopolitical reasons determine the interrelationships among the religious groups in Bangladesh. However, a new wave of "religious revivalism" among Muslims is being perceived nowadays, and the outcomes are evident: religious intolerance, rise of Islamic fanaticism as well as militant groups, and promulgation of Islamic sentiment in social life, Islamization of education and mushrooming madrasa, etc.

\section{Communalism: Bangladesh Context}

To examine and perceive the nature of Bangladesh communalism and religious orthodoxy, it is imperative to study historical background of the religious politics in Bengal as well as Indian subcontinent. The confrontational politics was enacted between the two major religious communities: Hindu and Muslim by the British rulers in colonial regime, chiefly after Sepoy Mutiny in 1857. "Divide and Rule" policy sanctioned by the British facilitated communal tension; the motive was simple: to exploit the both groups. Emergence of the Muslim League based on religious nationalism countering the stance of Congress was a massive blow in the communal history of the subcontinent. But its popularity only began in 1930s. Bengal as a province was comparatively secular, and the Nikhil Bharat Krishak Proja Party as a secular political party led by A.K. Fazlul Haque secured huge support from Bengal (Sarkar, 2016). The reluctance of the Congressmen in forming coalition with Haque compelled him towards Muslim League, which has been considered as one of the foremost tragedies in the history of Bengal (Rafique, 2015). Afterwards, people of Bengal positioned behind the Muslim League led by Muhammad Ali Jinnah and thus an important shift in politics has begun: Bengal too plunged into the politics of separatism and thrived to achieve Pakistan. After the omega of colonial rule, a utopian state of "Pakistan" came into being in 1947, and a new struggle of East Pakistanis had started.

East Pakistan waged a war owing to 23-years' disparity and oppression led by West Pakistan rulers. A dreadful nine months war in 1971 brought a prestigious victory for the Bengal people, and "Bangladesh" has been emerged as a sovereign nation-state. Tajuddin Ahmed for the first time declared democracy, socialism, and secularism as the base of the newly formed Bangladesh (Hasan, 1986). With the consent of Sheikh Mujibur Rahman, the four fundamental principles: democracy, nationalism, socialism, and secularism were added in the first Constitution (Part II: Fundamental Principles of State Policy) of the country in 1972 (Govt. of Bangladesh, 1972). Nevertheless, the essence of secularism as a spirit and principle of Liberation War had been tarnished in the very decade of its promulgation: firstly, by Ziaur Rahman (inclusion of Bismillahir Rahmanir Rahim at the starting of the constitution), and then Hussain Muhammad Ershad (declaration of Islam as the state religion). Islamist parties' active role in current Bangladesh politics also denotes the demise of secularism and the impossibility of peaceful co-cultural coexistence.

\section{Rise of Digital Communalism}

The demolition of the historical Babri Masjid by fanatic Hindus in 1990 in Gujrat had prepared a stage of religious disunity in Bangladesh. Islamic extremists in Bangladesh caused a great damage to the local Hindus afterward the attack in India (Azad, 1998). Such practice of retaliation is still ongoing, but the dimensions have been changed to a great deal due to the free and massive flow of information.

In earlier days, information was not so abundant so that people had to rely on traditional information sources. The inception of digital media has opened a vast territory of information, and people often unable to choose the reliable one and can be misguided. Following the same strategy, by throwing off distorted information, a large portion of religious community can easily be mobilized against other communities what Bangladesh has been experiencing. Social media during any communal tension is overflowed with fake information and doctored photos (e.g. burning Tibetan activist, Chinese earthquake victims, African accident victims) those have enough potential to excite the mobs (Adhikary \& Habib, 2016). Even the Counter-Terrorism and Transnational Crime (CTTC) cyber unit has identified almost 2,500 Facebook 
pages those are currently circulating communal hatred and religious extremism in Bangladesh (Hasan, 2017). The pattern, motive, and characteristic of two representative (one against Hindus, and another against Buddhists) digital communal violence are being analyzed.

\section{Assault on Hindu minority in Nasirnagar:}

In the afternoon of 30 October 2016, nearly 3000 fierce people shattered 17 temples, and vandalized and looted around 100 houses in several villages of Brahmanbaria's Nasirnagar (Chakraborty, 2017b). More than hundred people were injured and six families left the country right after the incident. The driving force behind such two-hour long atrocity was merely an alleged Facebook post "defaming" Islam and a Hindu illiterate fisher named Rasraj Das was convicted for this act. Although being perplexed, he pleaded his innocence denying this "false" allegation (Sakhawat, 2016).

Despite of demanding his guiltlessness, Rasraj was beaten heavily and submitted to jail. However, further investigation and Vox-pop of the locals delineate a parallel picture of how the violent mob was constructed, incited, and thereafter unleashed upon the Hindu minorities of the surrounding areas. The local mosques protested the "defamatory Facebook post by a Hindu" in Norpur, Asurain, Phulpur, Pandao, Capartala, Kaliuta, Guniag, and Bolapur villages; of them, some are the stronghold of radical Islamists.

The radical Islamist groups Ahle Sunnat Wal Jamaat and Hefazat-e-Islam organized and conducted the violence. Islamic radicals use mosque to unite Muslims to administrate mayhem upon local Hindus. Evidences show the involvement of Chhatra Shibir, a student wing of Jamaat-e-Islami in spreading hate speeches and posts using social media which later causes series attacks on Hindu temples and Puja pavilions in at least seven districts including Brahmanbaria (Sarker \& Miazee, 2016).

What about the Facebook post which triggered one of the country's largest communal attack? The Information Communication Technology (ICT) specialists within three days of the mayhem had hinted about the possibility of digital disinformation. Some of the prominent ICT experts from BUET, CounterTerrorism and Transnational Crime (CTTC) and Criminal Investigation Department (CID) expressed the plausible chance of hacking of Rasraj's Facebook account to circulate communal hatred (Khan \& Siddique, 2016). After investigation, it was clear enough that someone else than Rasraj did the job to arise communal hatred among local Muslims against Hindus to perpetrate such savagery.

After few days of the mayhem, "Dewan Atikur Rahman alias Ankhi, Chairman of Haripur Union Parishad and prime suspect of the attacks on Nasirnagar
Hindus, confessed to paying for the truck that carried the attackers" (Chakraborty, 2017a). Several accounts of villagers along with Fisheries Minister Sayedul Haque opined that Rasraj did not generate the defamatory Facebook post because of being illiterate. He also hinted about secret plot behind this abominable incident (Sakhawat \& Hasan, 2016). Nevertheless, how exactly the disinformation came about is still unknown. However, it is palpable that this planned act of vandalism and circulation of disinformation was to instigate and mobilize people to perform violence

\section{Attack on Buddhist minority in Ramu:}

On 29 September 2012, 12 Buddhist monasteries and at least 100 houses in Ramu were destroyed and looted because of an alleged desecration of the Quran in a fake Facebook account using the name of Uttam Barua, a Buddhist youth ("25,000 Muslim", 2012, "Extremists linked," 2012). The violence later spread to Ukhia and Teknaf in Cox's Bazar, and Patiya in Chittagong. An estimated 25,000 people participated in the violence in Ramu ("Rioting mob", 2012).

The group of attackers was allegedly comprised of local pro-Awami League leaders, BNP men, madrasa students, common people, and some Rohingyas. However, the much-talked Facebook photo of "Uttam's feet on Quran" was nothing but a deliberate and deceptive disinformation, and the accused was only tagged in the photo. Some Bangladesh journalists "saw the picture, shows white feet-wearing nail polish - on the Quran" (Ahmed \& Manik, 2012b).

Tofail Ahmed, chair of Naikhangchhari upazila of Bandarban was arrested in connection with attacking and vandalizing of a Buddhist temple at Ramu ("SC cancels", 2014). His nephew Muktadir instigated Ramu locals by showing fake photo (Manik, 2013) doctored by Omar Faruk, an ex-member of Chhatra Shibir.

The way the mob gathered also indicates something not spontaneous but plotted. On the $29^{\text {th }}$ evening, at most hundred-people started procession and rallies against the Ramu's Buddhists. However, the mob grew to around 6,000 overnight, in which most of the vandals were outsiders (Ahmed \& Manik, 2012a). Kaberi Gayen has identified the role of political figures of the affected area:

This is for the first time in Bangladesh

history, irrespective of political affiliation, that local leaders were involved in a communal attack on a minority population. Either they took part in agitating people leading the early processions, or they took part in arson and vandalism themselves, or they did not play the roles they had taken oaths for. (Gayen, 2012)

The demolishers came from the surrounding areas but not the local people, spectators commented. Then, who are 
they, why they came, and who did influence them to conduct mayhem? It is yet to uncovered. With this tragedy, a culture of violence on Bangladesh minorities through digital disinformation has started, and the legacy we saw in Joypurhat (Chowdhury, 2017), Rangpur ("Mayhem over", 2017), and few other places of the country.

\section{Why Digital Disinformation and Communalism}

Digital communication system would have narrow down the information gap across the globe and provide a new democracy. Then, why communal disintegration due to digital disinformation is happening at a large scale in Bangladesh is a fundamental question. To answer, historical perspective, contemporary geopolitics and socio-political environment, and behavioral psychology need to be taken into account.

\section{Counter-hatred:}

India surrounds Bangladesh from three sides considering the geographical landscape. Interdependency happens between neighboring countries, especially between those who share borders. Historically, India and Bangladesh have many pleasant and bitter memories in common. It is sooth to say that the partition of 1947 is still haunting the people of both countries. The seed of socio-political separation and animosity along religious line is very much alive to date, but the basic difference is: contemporary religious hatred is quite explicit, expressive, immense, and multilayered than the past with the aid of digital communication.

After independence, an anti-Indian sentiment had been developed due to manifold socio-political reasons during Mujib's regime. It forced to revive the "Muslim identity" and compelled Bengali Muslim community towards an Islamic revivalism that was about to die after the fall of undivided Pakistan (Ahmed, 2014). Zia and Ershad during 1975-90 reinforced the religious sentiment among Muslims due to political achievement. Thereby, anti-Indian sentiment, to some extent, was converted to anti-Hindu feeling. Recent trend is showing religious hatred and despise against local Buddhist community after the "genocide" and repulsion of Rohingya Muslims in Myanmar (Mahmud, 2017). Even the Hefazat-E-Islam having headquarter in Chittagong nearby Rakhine threatened to wage a war against Myanmar's inhumanity against their "Muslim brothers" (Joehnk, 2017). The counter-religious detestation is an "eye-for-eye" game: if you hurt my faith-mate in your country, I will hurt yours in my place.

\section{Communal language and digital contempt:}

Nobody other than co-cultural communities in any country understands the language of eyes and expressions of dominant culture. Dominant religious communities throughout the world tend to search for suitable ways to suppress other religious minorities by any means to sustain their supremacy. In Bangladesh, Muslims spontaneously humiliate Hindus in digital platform addressing them "Malaun" or "Malu", a derogatory term originated from Arabic means "accursed" or "deprived from God's mercy" (XY, 2014). Often Hindu people are scorned to leave Bangladesh as it has a Muslim majority and here is no place for Hindu "pagans". Following this logic, India is largely considered as "Hindu country" by the average Bengali Muslims. It is a post-partition legacy and thoughtprocess. Such detrimental ideation colonizes the mind of Bengali Hindus and coerces them to emigrate. Besides, Buddhists are often designated as infidel because Buddhism carefully ignores the concept of "God".

\section{Rumor as information:}

Rumor can be so powerful to shake the establishment, history is witness. The transmission of rumor has some distinctive features. A receiver of rumor tends to: (a) carry the most important parts of the rumor, dropping off the irrelevant; (b) detect misinformation in the rumor and eliminate it (Buckner, 1965); (c) transmit the rumor without changing it if he can detect no irrelevant or false information (Schachter \& Burdick, 1955). In Bangladesh, the impact of rumors is seemingly high because of this third feature.

We can demonstrate three major explanations behind this: (a) as a least developing country, Bangladesh is nurturing poor quality of population who have limited level of knowledge to distinguish what might be right or wrong; (b) in the age of information liquidity, individuals are bombarded thousands of information every consecutive day, thus people get confused about information quality and accuracy, and transmit them to others; (c) historically Bangladesh society is fostering traumas and fears within, and some rumors are favorable to instigate such hidden elements. Professor Dr. Salimullah Khan explains why Bangladesh people buy rumors from another point of view:

"Our minds are hungry, or thirsty if you prefer. If you are not going to feed them with the right stuff, they are going to purchase the wrong... Rumors spread the truth in a fictional way." (Yusuf, 2014)

People love stories those are weaved perfectly. Lacan (1977) opined that "truth is structured like a fiction" (p. 306). The digital dis-informants construct erroneous stories intentionally in a fictional style to allure more audience and cause more impact. A rumor becomes successful when it can play with public anxiety, trauma, fear, and interest. People then consume, get addicted, and therefore driven by rumor. Information nowadays is easier to receive, (mis)interpret, disseminate, deceive, and achieve desired effects. Thus, a rumor that cause communal crisis at one tiny place in one country can 
engender severe counter-hatred and religious bellicosity in another place of another country.

\section{Weaponization of digital public sphere:}

Ali Riaz (2015) argued the emergence of a new Islamic public sphere in Bangladesh in recent years comprising Islamic fiction (e.g. novel, story etc.), and Islamic study group (e.g. Halaqa and Taleem). What he failed to hypothesize is the emergence of new age "digital Islamic public sphere" and its weaponization against local religious and ethnic minorities. The "digital publics" as radical Muslims postulate and deny the legitimacy of the religious minorities in different manners. However, many corrupt politicians and interest groups in Bangladesh and India are using the digital platform to stage exclusive religiopolitical game.

Propagating communalism is a vicious but foolproof weapon to extract or achieve desired outcomes, most suitably, on the political context of the Indian subcontinent. Politicians here know that political maneuver using religious sentiment is so successful than anything else, and fanatics are too powerful to make anything happen. Russel extrapolated why and how fanatic creeds win over others:

"...a nation of united fanatics has more

chance of success in war than a nation containing a large proportion of sane men."

(Russel, 2004)

Bangladesh secularism has been impeded due to numerous political reasons, and legacy of religion-based politics continues as most people still misinterpret political play as "holy conquest". Previous two incidents of digital communalism prove that digital public sphere has now become a convenient instrument to organize and unleash ferocity either to accomplish self-interest or to incriminate the opposition.

\section{Communalism and modes of digital power:}

Power is having intended effects on others. It has many forms: economic, political, religious, communicative, technological, physical, etc. Digital cyberspace as a unique form of modern tool of power is getting its preference and becoming a game changer. Unlike anything in the world, digital cybersphere for the first time offers a realm of "pseudo-reality" to its users, thus attain immense power. Cyberspace has some distinctive features regarding information and communication: speediness, ubiquity, effectivity and interactivity, easy accessibility, and availability of alternatives. For these reasons, information in cyberspace is more fluid than any other communication channel. Besides, information can be diffused to a larger audience within the least possible time and cost. On the other hand, religion usually dwells on the most sensitive part of believers' emotion so that it is easy to incite a devotee using his faith. The combination of digital information and religion can simultaneously be peaceful and catastrophic based on its management and usage. If healthy information is disseminated through digital media, it will bring peace and association; and if not, then the opposite is bound to happen. Thus, using cyberpower, religious disinformation hampers social serenity.

Cyberpower, in context of Bangladesh communalism, has two distinctive faces: (a) authority; and (b) coalition those exert significant impact. Authoritative power over information in digital platform bespeak about its usage: if the information-holder is a wrong-doer then he will misguide people with the "engineered information" or disinformation. A unique nature of digital disinformation is a single body can mobilize a large community with greater force within the least possible time just with a tiny piece of information; the previous social-media instigated violence has already proven this statement. On the other hand, coalition plays a substantial role in executing vandalism. No isolated person can able to flare and devastate a community, rather it needs a motivated coalition. United manpower (e.g. Facebook-incited mob) is responsible for the damages.

\section{Conclusion}

Digitality is encaging individuals' public and private lives in Bangladesh rapidly and radically. The pace of digitalization seems simultaneously unusual and imbalanced. For this reason, information management and regulation are often impeded. It has nothing to do with "freedom of speech" but the ethical accommodation and transmission of information. When unprecedented information surrounds an individual, assuredly he needs to struggle to find out the right one. It is tough job though. Hence, most of the individuals usually find out the shortest route, derive and learn the information from the nearest possible source, and react. Thus, disinformation along with information find its extraordinary way of being succeed.

Digital disinformation to be successful, a range of factors play important role: the demographic nature (education, socialization, social orientation, and income), culture and belief (nature of belief, religious motivation, and practices), political atmosphere and nature of politicians (preference of religion in politics, and politician's morality), and measurement of digital knowhow (reach of digital culture, nature and number of digital dwellers, and source of information). When the material culture of society changes rapidly but the nonmaterial one is not so it tends to resist the material change, according to cultural lag (Ogburn, 1957). Communication technology as a material culture has been penetrating and revolutionizing the existing picture of Bangladesh society, but the prior belief and morality can not cope up with the material change, so it would, to some extent, try to defend the modernization process. 
Digital disinformation can be an expression of this propensity.

Meanwhile, the communal politics and fanaticism that is yet to eradicate from this land already has found its nest in digital hub. Malefactors have discovered a new way to fuel public outcry. To protect not only Bangladesh religious minorities but other co-cultural communities, digital disinformation must have to be prevented either by laws or by new strategies. It is imperative to cultivate technological benefits and grow digital culture amid Bangladesh society as an indication of social development and advancement. Though having demerits, digital communication is the ultimate gift of modernity. The appropriate management, supervision, and control over digital space and information would not only expel communal disinformation but also would accumulate more boons to the lives of religious minorities in Bangladesh.

\section{Correspondence to:}

Md. Sayeed Al-Zaman

Jahangirnagar University

Savar, Dhaka, Bangladesh.

Email: ovi.sayeed@yahoo.com

\section{References}

"25,000 Muslim rioters torch Buddhist temples, homes in Bangladesh" (2012, September 30). RT. Retrieved from https://www.rt.com/news/buddhist-templestorched-bangladesh-342/

Adhikary, Tihin Shubhra, \& Habib, Wasim Bin (2016, November 26). Fake photos trolling. The Daily Star. Retrieved from https://www.thedailystar.net/ frontpage/fake-photos-trolling-1320613

Ahmad, Mohiuddin (2014). Jashoder Utthan Poton Osthir Somoyer Rajniti. Dhaka: Prothoma Prokashan.

Ahmed, Inam, \& Manik, Julfikar Ali (2012a, October 02). Attack on Buddhists preplanned: Tearing out the soul. The Daily Star. Retrieved from https://www.thedailystar.net/news-detail-252079

Ahmed, Inam, \& Manik, Julfikar Ali (2012b, October 03). Attacks on Buddhist temples: A hazy pictures appears. The Daily Star. Retrieved from www.thedailystar.net/news-detail-252212

Azad, Salam (1998). Why Hindus are leaving Bangladesh? Kolkata: Shatantra Prokashani. pp. 4041. Retrieved from https://view.publitas.com/ liberationwarbangladesh/hindu-smprdaayy-ken-deshtyaag -krche-saalaam-aajaad/page/1

Bangladesh Telecommunication Regulatory Commission (BTRC) (2018). Internet Subscriber in Bangladesh November. Retrieved from www.btrc.gov.bd/content/internet-subscribersbangladesh-february-2018

http://www.chinamediaresearch.net
Berger, Yotam (2017, October 22). Israel Arrests Palestinian Because Facebook Translated 'Good Morning' to 'Attack Them'. Hareetz. Retrieved from www.haaretz.com/israel-news/palestinianarrested-over-mistranslated-good-morningfacebook-post-1.5459427

Bittman, Ladislav (1985). The KGB and Soviet Disinformation: An Insider's View. London: Pergamon Press.

Bromwich, Jonah Engel. (2016, February 04). Six Degrees of Separation? Facebook finds a smaller number. The New York Times. Retrieved from www.nytimes.com/2016/02/05/technology/sixdegrees-of-separation-facebook-finds-a-smallernumber.html

Buckner, HT (1965). A Theory of Rumor Transmission. Public Opinion Quarterly, 29 (1), 54-70. doi $10.1086 / 267297$.

Chakraborty, Ujjal (2017a, January 07). Nasirnagar attack: Chairman Ankhi confesses paying for vandals' truck. Dhaka Tribune. Retrieved from www.dhakatribune.com/bangladesh/crime/2017/01/ 07/nasirnagar-attack-chairman-ankhi-confessespaying-vandals-truck/

Chakraborty, Ujjal (2017b, October 29). One year of Nasirnagar attack: Rasraj is yet to get past the thin blue line. Dhaka Tribune. Retrieved from http://www.dhakatribune.com/bangladesh/lawrights/2017/10/29/one-year-nasirnagar-attackrasraj-yet-get-past-thin-blue-line/

Chowdhury, Md. Alamgir (2017, February 03). Another Nasirnagar-like plot in Joypurhat? Dhaka Tribune. Retrieved from https://www.dhakatribune.com/ bangladesh/crime/2017/02/03/now-joypurhat-hinduyouth-blamed-blasphemy/

“Extremists linked". (2012, October 01). The Daily Star. Retrieved from http://www.thedailystar.net/newsdetail-251955

Floridi, Luciano. (1996). Brave.Net.World: The Internet as a disinformation superhighway? The Electronic Libra., 14. doi: 10.1108/eb045517.

Floridi, Luciano (2005). Is Semantic Information Meaningful Data? Philosophy and Phenomenological Research, 70. doi:10.1111/j.1933-1592.2005.tb00531.x Floridi, Luciano (2011). The Philosophy of Information. London: Oxford University Press.

G. \& C. Merriam Co. (1961). Webster's Seventh New Collegiate Dictionary (14 ${ }^{\text {th }}$ ed.). Massachusetts: G. \& C. Merriam Company Publishers.

Gayen, Kaberi (2012). A Known Compromise, A Known Darkness: 'Ramu-nisation' of Bangladesh. Forum: A monthly publication of The Daily Star, 06 (11). Retrieved from http://archive.thedailystar.net/forum/ 2012/November/known.html

Government of the People's Republic of Bangladesh (1972). The First Constitution of the People's 
Republic of Bangladesh. Dhaka: Govt. of Bangladesh. Retrieved from https://constitute project.org/constitution/Bangladesh_2011.pdf

Hasan, Kamrul (2017, November 16). 2,500 Facebook pages spread communal hatred in Bangladesh. Dhaka Tribune. Retrieved from https://www. dhakatribune.com/bangladesh/2017/11/16/hundreds -facebook-pages-spreading-communal-hatredbangladesh/

Hasan, Maidul (1986). Muldhara '71 (2 ${ }^{\text {nd }}$ ed.). Dhaka: The University Press Limited. Retrieved from https://www.liberationwarbangladesh.org/2014/07/ blog-post_67.html

Hassan, Md. Kamrul (November 20, 2016). "No Hindus will be left after 30 years". Dhaka Tribune. Retrieved from https://www.dhakatribune.com/bangladesh/ 2016/11/20/abul-barkat-632-hindus-left-countryday

Hauben, Michael F. (1995, November). The Netizens and Community Network. Paper presented at the Hyper Network '95 Beppu Bay Conference, Japan.

Hern, Alex (2017, October 24). Facebook translates 'good morning' into 'attack them', leading to arrest. The Guardian. Retrieved from https://www.theguardian. com/technology/2017/oct/24/facebook-palestineisrael-translates-good-morning-attack-them-arrest

Hume, David (2007). Of Liberty and Necessity. Millican, Peter (ed.). An Enquiry Concerning Human Understanding. London: Oxford University Press.

Huntington, Samuel P. (1996). The Clash of Civilization and the Remaking of World Order. New York: Simon \& Schuster.

Joehnk, Tom Felix (2017, October 06). How the Rohingya crisis is changing Bangladesh? The New York Times. Retrieved from https://www.nytimes.com/ 2017/10/06/opinion/rohingya-bangladeshmyanmar.html

Khan, Mohammad Jamil, \& Siddique, Mohammad Abu Bakar (2016, November 02). Cyber sleuths probing FB post that sparked anti-Hindu violence. Dhaka Tribune. Retrieved from http://www.dhakatribune.com/ bangladesh/crime/2016/11/02/cyber-sleuthsprobing-bbaria-fb-post/

Lacan, Jacques (1977). Écrits: A Selection (Alan Sheridan, Trans.). London: Tavistock Publications.

Mahmud, Tarek (2017, September 19). Rohingya crisis: Security amped up at Buddhist temples. Dhaka Tribune. Retrieved from https://www.dhakatribune. com/bangladesh/nation/2017/09/19/rohingya-crisissecurity-buddhist-temples/

Manik, Julfikar Ali (2013, November 28). Mastermind of Ramu attacks arrested. Dhaka Tribune. Retrieved from https://www.dhakatribune.com/law-andrights/2013/11/28/mastermind-of-ramu-attacksarrested/
"Mayhem over Facebook post" (2017, November 11). The Daily Star. Retrieved from https://www. thedailystar.net/frontpage/mayhem-over-facebookpost- 1489402

Minority Rights Group International (2016). Under Threat: The challenges facing religious minorities in Bangladesh. Sweden: Minority Rights Group.

Mohsin, A. (2003). The Chittagong Hill Tracts, Bangladesh: On the difficult road to peace. London: L. Rienner.

Ogburn, W. F. (1957). Cultural lag as theory. Sociology \& Social Research, 41, 167-174.

Pacepa, I. M., \& Rychlak, R. J. (2013). Dis information: Former Spy Chief Reveals Secret Strategies for Undermining Freedom, Attacking Religion, and Promoting Terrorism. New York: WND Books.

Rafique, Ahmad (2015). Deshbibhag: Fire Dekha (2 ${ }^{\text {nd }}$ ed.). Dhaka: Anindya Prakash.

Riaz, Ali (2015). How Did We Arrive Here? Dhaka: Prothoma Prokashan.

"Rioting mob torches temples in Bangladesh" (2012, September 30). ABC News. Retrieved from http://www.abc.net.au/news/2012-09-30/rioterstorch-buddhist-temples-in-bangladesh/4288598

Rowley, Jennifer (2007). The wisdom hierarchy: representations of the DIKW hierarchy. Journal of Information and Communication Science, 33 (2), 163-180. doi: 10.1177/0165551506070706

Russel, Bertrand (2004). Power: A New Social Analysis. London: Routledge.

Sakhawat, Adil (2016, November 02) Nasirnagar attacks driving away Hindus. Dhaka Tribune. Retrieved from http://www.dhakatribune.com/bangladesh/ crime/2016/11/02/nasirnagar-attacks-driving-awayhindus/

Sakhawat, Adil, \& Hasan, Kamrul (2016, November 05). Minister Sayedul: Rasraj too undereducated to post on Facebook. Dhaka Tribune. Retrieved from http://www.dhakatribune.com/bangladesh/2016/11/ 05/rasraj-illiterate-post-facebook/

Sarkar, Monayem (2016). A Brief History of Bangladesh ( $3^{\text {rd }}$ ed.). Dhaka: Agami Prokashani.

Sarker, Probir Kumar, \& Miazee, Manik (2016, November 05). Shibir-run website incites Nasirnagar attacks. Dhaka Tribune. Retrieved from http://www.dhakatribune.com/ bangladesh/ crime/2016/11/05/shibir-website-incitesnasirnagar-attacks/

"SC cancels key Ramu attacker's bail" (2014, May 12). The Daily Star. Retrieved from https://www.thedailystar.net/sc-cancels-key-ramuattacker-s-bail-23781

Schachter, S, \& Burdick, H. (1955). A Field Experiment in Rumor Transmission and Distortion. Journal of Abnormal and Social Psychology, 50 (3), 363-371. Doi: https://psycnet.apa.org/doi/10.1037/h0044855 
Smith, David. (2008, August 03). Proof: Just six degrees of separation between us. The Guardian. Retrieved from https://www.theguardian.com/technology/ 2008/aug/03/internet.email

XY, Charlie (2014). Urban Dictionary. Retrieved from https://urbandictionary.com/define.php?term=Mala un

Yusuf, Ananta (2014, January 24). The origins of communalism. The Daily Star. Retrieved from https://www.thedailystar.net/the-origins-ofcommunalism-7950

Zins, Chaim (2007). Conceptual Approaches for Defining Data, Information, and Knowledge. Journal of the American Society for Information Science and Technology, 58 (4), 479-493. doi: 10.1002/asi

$3 / 28 / 2019$ 